\title{
Water Resources Potentialities in the Wadi Mellegue Basin,Tebessa Region, Northeastern Algeria
}

\author{
Guerrad $\mathrm{Ch}^{1} \&$ Ch. Fehdi ${ }^{2}$ \\ ${ }^{1}$ Faculté des sciences, Université de Skikda, Algérie \\ ${ }^{2}$ Department of Geology, Tebessa University, Algeria \\ Correspondence: Chemseddine Fehdi, Route de Annaba Nº71. Tébessa 12000 Algeria. Tel: 213-7229-3267. \\ E-mail: fehdi@yahoo.fr
}

Received: February 13, 2017

Accepted: February 20, 2017 Online Published: June 6, 2017

doi:10.5539/jgg.v9n2p66

URL: http://dx.doi.org/10.5539/jgg.v9n2p66

\begin{abstract}
The problem of water is inseparable from sustainable development insofar as water must make it possible to meet the needs of present generations without mortgaging; the ability of future generations to meet their own needs. The first concern in semi-arid populated areas; it is the availability of water in relation to a growing societal demand.

The immediate objective of a strategy for conserving and improving the productivity of water resources is to halt degradation with all its known forms and to promote a sustainable economy that will preserve and even enrich the quality of the assets And predispositions identified at the regional level. Tebessa is considered a semi-arid environment characterized by the rarity and the random nature of the resources, linked to an unpredictable climate and highly variable from one year to the next; The "sheep region", the "pastoralism", the "nomadism", the vegetable production very seriously compromised both by: The scarcity of the water resource, the fragility of the soil, the poverty of the mode of production, Pastoral type, based on the constant mobility of the herd in search of palatable plant cover, inducing a seemingly irreversible effect of desertification The progressive generalization of a mode of "mining" exploitation, made possible by the increasingly widespread use Modern means of transport, food, communication of information ...

In this study, we examine the main water resources of Wadi Mellegue basin, available renewable water resources; The prospects for changing demand and the risks of scarcity.
\end{abstract}

Keywords: Tebessa, Medjerda, Wadi Mellegue basin, management, water potential, sustainable development

\section{Introduction}

Water is a natural habitat, whether abundant or rare, determines the characteristics of its other components (soil, fauna, flora, erosion, wetlands, arid zones, etc.) Water is also the basis of the relations of men to nature and men to each other. Water is a factor of economic production, comfort and health, environmental amenity and ecological balance. Its poly functionality, associated to its rarity gives it a value of use, a patrimonial dimension and in fact a material support of the social imaginary.

According to Marillys Mace, we call water resources or water resources all accessible waters that we have available to satisfy and cover all our needs and the proper functioning of our ecosystems. As groundwater and surface water resources in semi-arid countries are the limiting factor for any economic development, knowledge of the adequacy between hydrological conditions and the availability of surface and underground water is a tedious but necessary step for any plan of development. Beyond a predictive model oriented towards immediate management needs, a methodological approach should be envisaged in order to describe and quantify the mechanisms of recharges and discharges of aquifers in these semi-arid environments characterized by a pluviometric regime of high variability.

Awareness of the challenges posed by this increasingly demanded and coveted natural resource and vulnerability have led to national and even international policies and strategies in all countries of the world, integrating the assessment of available resources, Potential / demand balances, intersectoral and / or interregional allocation modes, production costs, crisis management, protection against factors of degradation or abuse. 
- Social issues:

- All Algeria including the Tébessa wilaya live in a zone of water stress $\left(600 \mathrm{~m}^{3}\right.$ / inhab / year),

- Not all populations perceive the same water service

\section{- Environmental and heal th issues:}

Many wadis and lakes are polluted; All aquifers are overexploited, biodiversity has declined in all freshwater rivers,

\section{- Food issues:}

- Water is an essential element in agricultural production, 70\% of water consumption in Algeria goes to irrigation,

- Economic and financial issues:

- Creation and development of large and small private and public companies in the field of water

- Political and geopolitical issues:

- Stability of populations and improvement of their well-being.

- Management of transboundary river basins and aquifer systems.

Among the many actors in water, geographers are challenged to contribute to a global approach to the resource, in which the objective of this work falls. The region of Tebessa and its periphery has enormous difficulties in controlling its water resources. Issues related to the use and management of water refer to problems upstream of the diet of the different poles of consumption; Populations, Agriculture, Industry. The relationships and interdependencies thus established highlight two levels of concern totally intertwined: The degree of fragility of the physical environment that acts on the lack of mobilization of the resource in the region studied the scarcity and irregularity of the precipitation resulting in By large water deficits.

\section{Water: A Concerning Equation}

While in the not-distant past a certain balance has been achieved between capricious and fragile resources and relatively stable human needs, we have for some time witnessed increasing tensions in these resources, due mainly to the combined effects of socio- Economic growth of the country, population growth but also an unfavorable climatology characterized by a significant irregularity of precipitation and an increasing water deficit. These tensions, which underline the importance of the water factor in any planning and management strategy, require a rigorous analysis of the evolution of needs, as well as an assessment of the conditions under which they could be satisfied on average and long term.

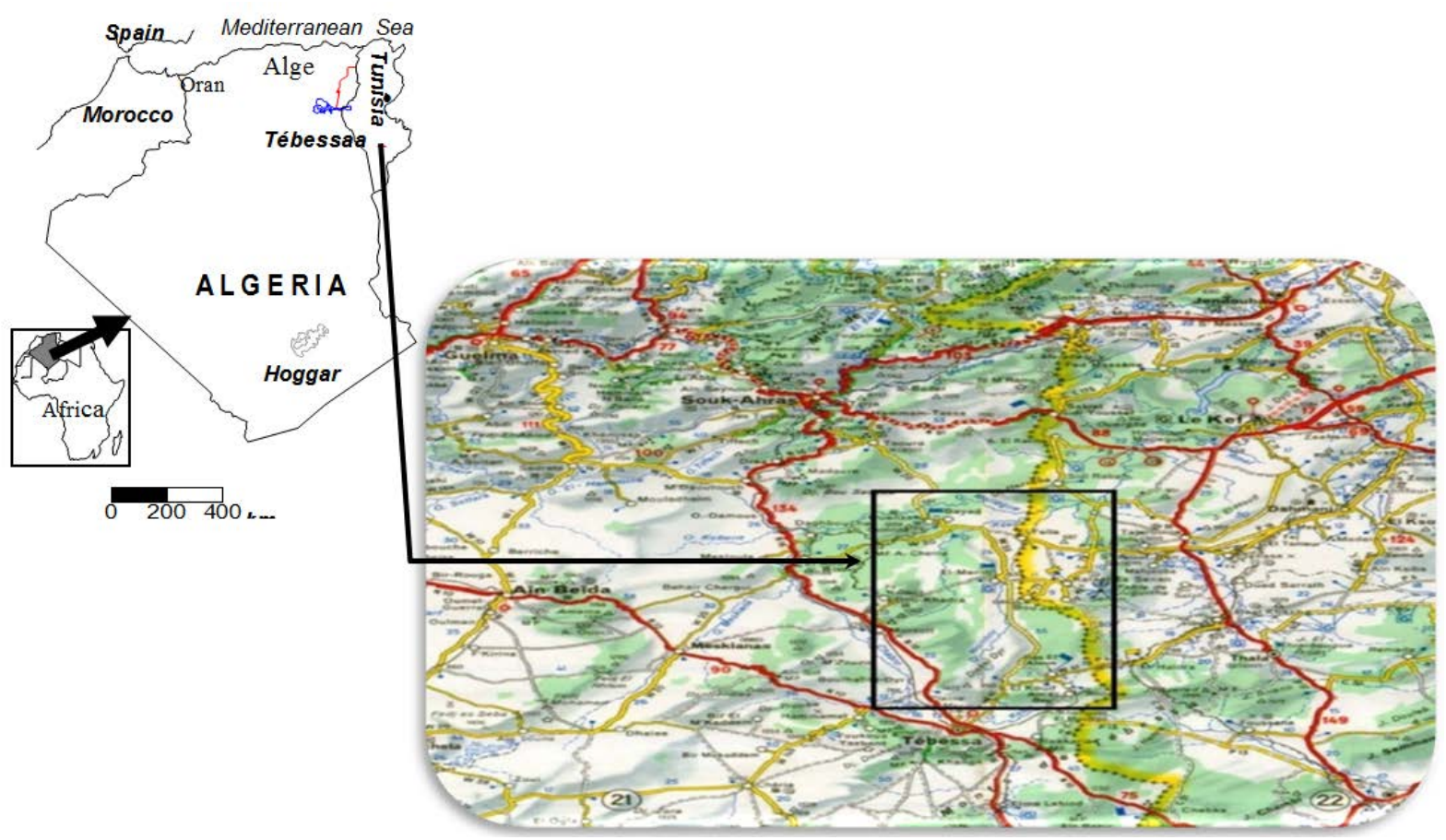

Figure 1. Location of the study area

In fact, the problem of water is that of sustainable development insofar as water must be able to meet the needs 
of present generations without compromising the ability of future generations to meet their own needs. Meeting increasing needs with limited resources, developing better management and arbitration mechanisms, finding the most viable trade-offs between levels of demand satisfaction on the one hand and conservation of the natural environment and conservation of resources On the other hand, to bear investment and operating costs that can grow faster than the growth of the economy, these are the challenges facing the water sector in the Wilaya of Tebessa.

\section{Water Resources Mobilization}

The southern latitude, or the mountainous shield of the tell, make the study area a semi-arid area par excellence. This area is characterized by a continental Mediterranean climate: a hot and very dry summer with high temperatures and a humid winter And cold.

The low precipitation, due to the semi-arid character of the region on the one hand, and the lack of environmental studies making the task of localization of groundwater resources difficult on the other hand, are a major concern.

The increase in industrial consumption, domestic consumption, the large losses due to pipeline conditions and evaporation, mean that the endowment required for crops grown in quantities of water is never reached.

\subsection{Surface Water Potential: A Poor Annual Distribution}

The superficial water resource comprises all the waters of the wadis; Dams; And hill catchments which are for the most part intended for irrigation except for dams which are after treatment intended for the supply of drinking water to agglomerations

\subsection{The Wadi}

The Oued Mellègue downstream catchment is located in the northern part of Tebessa, with an area of 1082.94 km2 (part of which belongs to the Tebessa region); This basin is limited to the north by the Upper Oued Mellègue sub-basin, to the south by the basin of Oued Chabro; To the west by the sub-basin Oued Mellègue upstream and the Basin of Oued Chabro, and to the east by Tunisia. The site is integrated into the "MEDJERDA" hydrographic system. The confluence of Oued Medjerda (Souk-Ahras) and Oued Mellègue gives birth to Oued Medjerda, (Main watercourse of the Medjerda basin). Oued Mellègue results from the junction of the two wadis: the 1st Wadi Mellègue Amont which in a direction SO-NE, the 2nd Wadi Mellègue Aval it is the result of the confluence of Oued Kseub, Oued Horiher, Oued El Baiad, Oued El Harcha , And Oued Samama (Figure 2).



Figure 2. Hydrographic network

The hydrographic network of the Oued Mellègue river drainage basin reflects the modesty of its rainfall, it is constituted of wadis with perennial flow (oued Kseub with a length of $20.17 \mathrm{~km}$, oued Horiheur $30.57 \mathrm{~km}$ and intermittent (example oued Erkel $15.92 \mathrm{~km}$ oued sammaa $16.78 \mathrm{~km}$ ). 
The graph below (Figure 3) represents the main wadis of the Oued Mellegue downstream catchment whose length exceeds ten $(10) \mathrm{km}$.

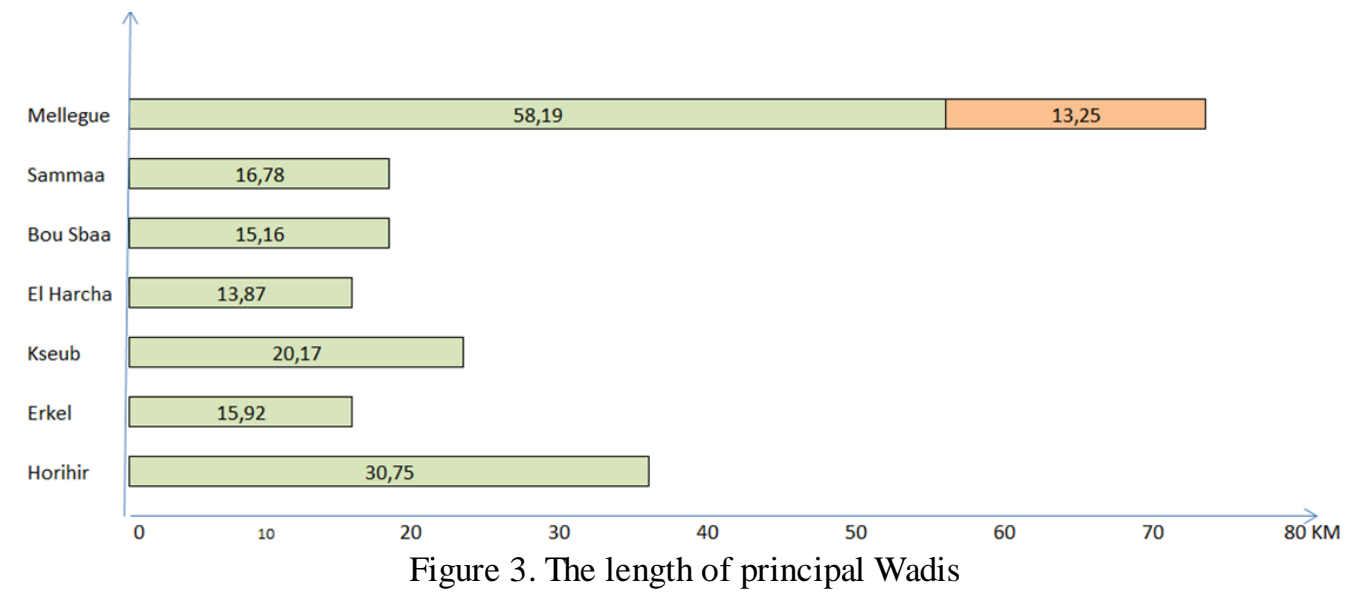

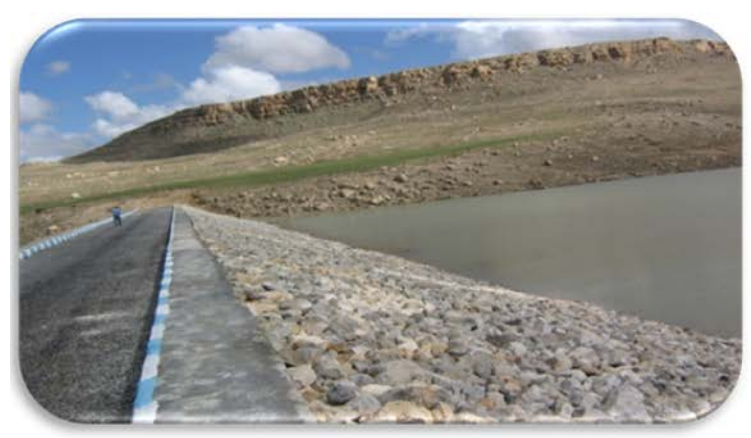

AINELBEY

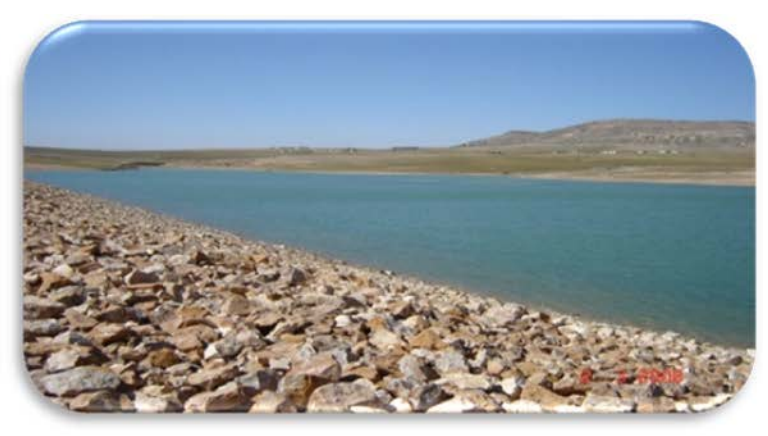

ALBRIK

Figure 4. Two dams at El Kouif locality

\subsection{Collinar Dams and Retention}

The region has a water supply thanks to the multiple projects realized in the field of the resources and these achievements require accompaniment and rationalization of the exploitation of the water According to data provided by the Tébessa Water Resources Directorate; The Oued Mellègue sub-catchment has 04 hill reservoirs and a dam with a capacity of $2.02 \mathrm{hm} 3$ reserved for feeding the area with drinking water (table 1) and for the irrigation of several hectares of agricultural land; Next to the entry into operation of an irrigated perimeter in the commune of Ain Zerga (240hz We do not forget to recall the emergency measures taken including feeding the wilaya from the dam. Of Ain Dalia which helped to "alleviate" the region's chronic deficit in this vital commodity.

Table 1. Principal dam in the study area

\begin{tabular}{|c|c|c|c|c|c|c|c|c|c|}
\hline \multirow{2}{*}{$\mathbf{N}^{\circ}$} & \multirow{2}{*}{ area } & \multirow{2}{*}{ Name } & \multirow{2}{*}{ Type } & \multicolumn{2}{|c|}{ Coordinats Lambert } & \multirow{2}{*}{$\begin{array}{c}\text { Volume } \\
\left(\mathbf{M}^{3}\right)\end{array}$} & \multirow{2}{*}{ Cost (DA) } & \multirow{2}{*}{ Year of accomplishment } & \multirow{2}{*}{ Destination } \\
\hline & & & & $\mathrm{X}(\mathrm{km})$ & $\mathrm{Y}(\mathrm{km})$ & & & & \\
\hline 01 & EL KOUIF & EL BRIKA & Retenue & 1012,70 & 225,20 & 1.025 en $\mathbf{H M}^{3}$ & $94.506 .975,60$ & 2006 & Irrigation \\
\hline 02 & EL KOUIF & AIN EL BAY & Retenue & 1007,70 & 260,50 & 0.224 en $H_{M}^{3}$ & $66.114 .103,54$ & 2009 & Irrigation \\
\hline 03 & EL MERIDJ & EL BAYADH & Retenue & 995,30 & 288,50 & 0.047 en $M^{30}$ & l & 1985 & Irrigation \\
\hline 04 & EL MERIDJ & HORIHER & Retenue & 1001,90 & 297,40 & 0.064 en $M^{3}$ & l & 1985 & Irrigation \\
\hline 05 & AIN ZERGA & AIN ZERGA & Petit Barrage & $\begin{array}{l}1001,71 \\
1002,14\end{array}$ & $\begin{array}{l}275,95 \\
276,46\end{array}$ & 2.02 en $\mathbf{H M}^{3}$ & $516.813 .453,00$ & 2016 & AEP/Irrigation \\
\hline 06 & AIN ZERGA & AIN ZERGA & Périmètre irrigation & 1001,90 & 297,40 & I & 96103675,98 & 2016 & Irrigation \\
\hline
\end{tabular}


The location of groundwater remains difficult, especially with the drilling of boreholes which do not always give satisfactory results.

Underground resources are the most coveted despite their hypothetical nature.

The precise knowledge and control of hydrogeological data becomes more evident and deserves special and thorough attention. Studies carried out in the Oued Mellègue downstream catchment have highlighted the existence of several aquifer systems distributed over all the study areas (Table 2).

Table 2. Aquifer potentialities in the study area

\begin{tabular}{lcc}
\hline \multicolumn{1}{c}{ Aquifers } & Potentialities $\mathbf{H M}^{\mathbf{3}}$ /year & Consumption $\mathbf{H M}^{\mathbf{3}}$ /year \\
\hline Tebessa-Morsott & 21.5 & 30.5 \\
El Kouif & 2 & 1 \\
AIN Zerga & 2 & 1 \\
El ma Labioud & 11 & 12 \\
El Meridj & 1 & 0.5 \\
Gourigueur & 5.5 & 1 \\
Ain Chenia & 1.5 & 1 \\
Negrine & Estimation $800 \mathrm{l} / \mathrm{s}$ & $/$ \\
\hline
\end{tabular}

The majority of the underground water potential is pumped out from a drilling battery located mainly in the southeastern part of the Oued Mellegue sub-catchment (El koiuf and Ain Zerga). The latter has 11 boreholes, In good and bad condition) distributed over the entire area of the study area, $73 \%$ of which are used to supply the population with drinking water from the various municipalities in the region, managed by the CPA or the ADE , Mobilizing an average flow of $7.75 \mathrm{l} / \mathrm{s}$. The remaining boreholes mobilizing an average flow of $4.16 \mathrm{l} / \mathrm{s}$ exploited for the irrigation of agricultural land. Located at Ain Zerga, AZ1bis represents the deepest drilling (300m) with an exploited flow of $10 \mathrm{l} / \mathrm{s}$ and in El Kouif; BE1 represents the most powerful with an exploited flow of the order of $22 \mathrm{l} / \mathrm{s}$.

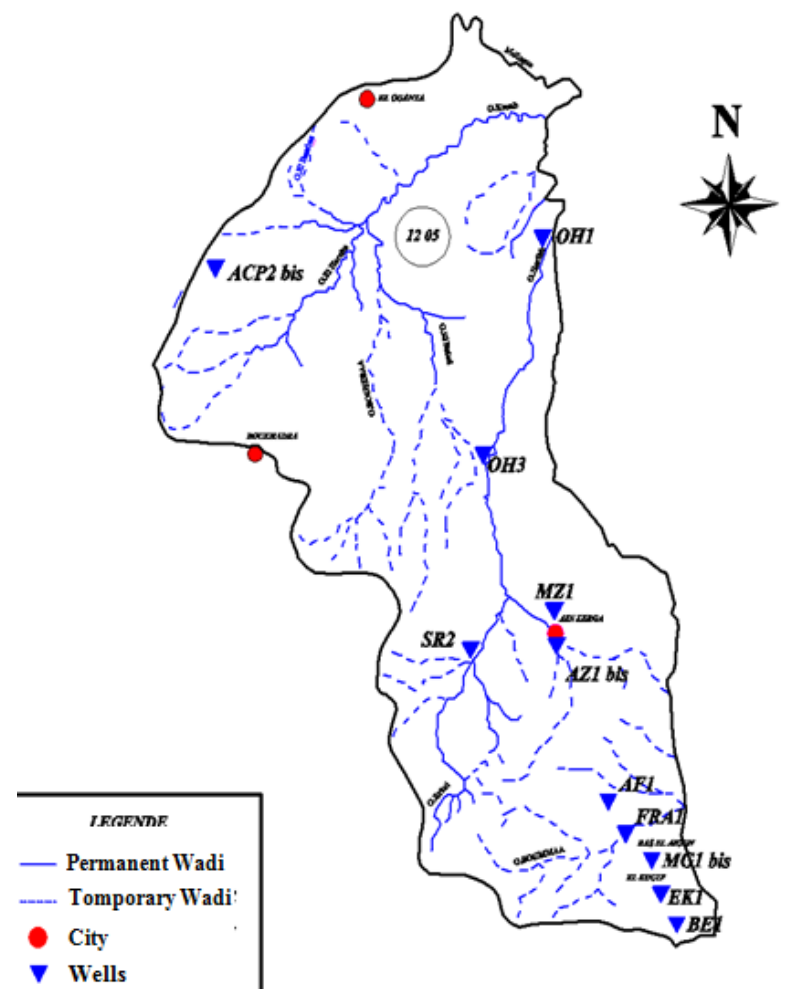

Figure 5. Principal Wells in the study area 

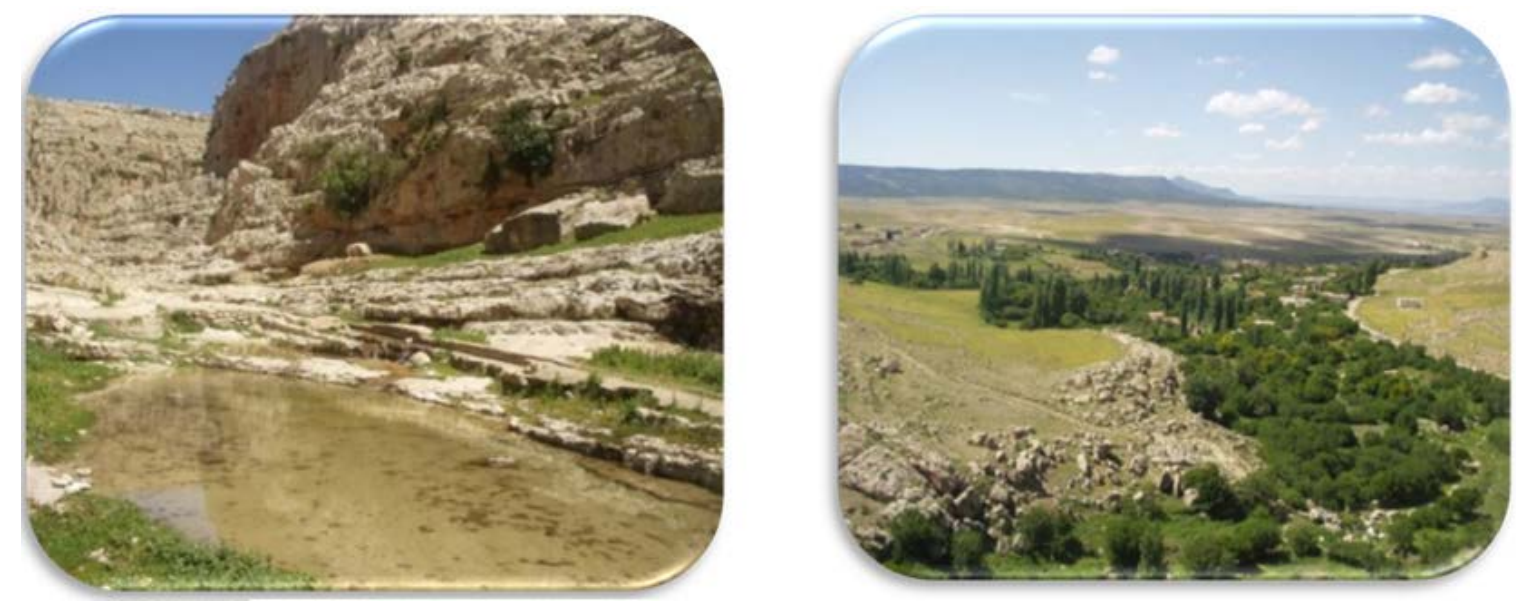

Figure 6. Gastel touristic zone

\subsection{SPRINGS}

The table below shows the different sources located at the level of the Oued Mellègue sub-catchment, of which (04) the majority of which is collected, ensuring the supply of drinking water in the same commune or they are with Flow rates ranging from $2-4 \mathrm{l} / \mathrm{s}$.

\subsection{WELLS}

Adding to the drilling a set of wells (declared: 04) which collects the superficial layers of the region; Designed to supply the drinking water or irrigation needs of some 100 hectares of local communities with flow rates ranging from 2 to $5 \mathrm{l} / \mathrm{s}$. The wells are not surveyed, the inventory is taken from the authorizations granted to the farmers.

Table 3. Different springs in the study area

\begin{tabular}{lccccc}
\hline Basin & Area & Localisation & Wilaya & $\begin{array}{c}\text { Exploitation flow } \\
\text { (L/S) }\end{array}$ & Destination \\
\hline 1205 & Ain zerga & Ain zerga & Tebessa & 4 & irrigation \\
1205 & Gastel & Gastel & Tebessa & 2.5 & domestic use +irrigation \\
1205 & Mesloula & Mesloula & Tebessa & 2 & domestic use \\
1205 & Ain bouzgoug & Bouzoug & Tebessa & 3 & domestic use +irrigation \\
\hline
\end{tabular}

Table 4. Different Wells in the study area

\begin{tabular}{llllcccc}
\hline Code MRE & basin & name & Localisation & area & flow (l/s) & Depth (m) & Destination \\
\hline P1203009 & 1203 & Dib Yahia/Amor & El kouif & El kouif & 2 & 40 & Irrigation \\
P1203010 & 1203 & Souahi Med El Hadi & El kouif & El kouif & 2,8 & 50 & Irrigation \\
P1203011 & 1203 & Souahi Med El Lamine & El kouif & El kouif & 5 & 50 & Irrigation \\
\hline
\end{tabular}

Table 5. Situation of sanitation network in the study area (Dec 2014)

\begin{tabular}{ccccccc}
\hline Communes & $\begin{array}{c}\text { Population } \\
\text { 2014 }\end{array}$ & $\begin{array}{c}\text { Population } \\
\text { concerned (inhab.) }\end{array}$ & $\begin{array}{c}\text { Consistance of the } \\
\text { network }\end{array}$ & $\begin{array}{c}\text { State of the } \\
\text { network }\end{array}$ & $\begin{array}{c}\text { Date of } \\
\text { accomplissement }\end{array}$ & Manager \\
\hline El Aouinet & 27844 & 1000 & Must be renovate & imperfect & 1985 & APC \\
El Kouif & 23014 & 3000 & Must be renovate & imperfect & 1978 & APC \\
Morsot & 23674 & 3000 & $/ /$ & imperfect & 1950 & APC \\
Boukhadra & 14648 & 1540 & $/ /$ & imperfect & 1987 & APC \\
Ouenza & 66939 & 3300 & $/ /$ & bad & 1987 & EPEDEMMIAT \\
Ain zerga & 27771 & 2765 & renovate & good & 1980 & APC \\
El Meridj & 15046 & 200 & good & good & 1980 & APC \\
\hline
\end{tabular}




\subsection{Current Situation of the Human Consumption Water in the Wadi Mellegue Basin Aval}

One of the major concerns of the public authorities of the downstream Wadi Mellegue basin is to solve the thorny equation between water resources and the satisfaction of the needs of the populations. Assessing this ever-increasing demand depends on several socio-economic factors such as demographics; standard of living ; The type of habitat and the socio-cultural habits.

The problem of the deficit in drinking water supply lies not in the drinking water resources but in the management of these resources. On the basis of international standards, and in particular those of WHO, we have adopted the staffing targets per day and per capita.

- $150 \mathrm{l}$ / d / inhab. For agglomerations whose population $<50,000$ inhab.

- $250 \mathrm{l}$ / d / inhab. For agglomerations whose population> 500,000 inhab.

- Between 150 and $250 \mathrm{l} / \mathrm{d} /$ person. (Linearly) for agglomerations with populations between 50,000 and 500,000 inhabitants.

- $80 \mathrm{l} / \mathrm{d} / \mathrm{h}$. For the rural population.

It is clear that the allowances under these standards are high, but it gives us great confidence in calculating drinking water requirements, especially in the future.

According to current data, the water balance of resources / needs of the study area in the medium and long term will be deficient and it is also noted that the relatively long maturation of water projects the limitation of resources, rapidly changing needs Important and sometimes competing demands for high infrastructure costs mean that actions in this sector, even more so than others, must be prepared well in advance in order to allow the choice of the best technical solutions, that is solutions The least costly for maximum use of the resources mobilized.

\section{Sanitation}

Inscribed within the framework of the decentralized sectoral programs (PSD); For 2013; The operation concerns the renewal of a sewerage network of more than $31 \mathrm{~km}$ and the construction of a second pipe for the drainage of sewage from the town of Ouenza 50000 habitants.

Tebessa has benefited within the framework of the current five-year period, of about 20 sanitation operations representing a public investment of around 10.5 billion dinars, an effort which, according to the same source, Four major wastewater collectors of 600 and 1,200 mm in Ouenza and three other municipalities, and three lagoons, under construction in Boukhadra and two other municipalities.

\section{Conclusion and Recommendations}

The improvement of water resources lies essentially in the solution of the problems of spatial and temporal distribution of the water supply, which is circulated through the mechanisms of the water cycle, without neglecting the quantitative aspects, Which are often decisive for both uses and ecological balance. The solutions must necessarily be adapted to both the characteristics of the natural resource, which depends on climate, geology, topography and needs requirements. Limiting factor remains the means that can be allocated, taking into account the other needs of economic and social development.

The region of Tebessa and its periphery have enormous difficulties in controlling its water resources. Issues related to the use and management of water in the region of Tebessa refer to problems located upstream of the diet of the different poles of consumption; Populations, Agriculture, Industry. The economic and social development in the wilaya is therefore largely dependent on a water policy, interconnected with the major strategic choices for development and land use planning. The outcome is already reflected in important achievements that have significantly improved the situation in the region.

Faced with this situation, and in order to meet the challenges posed by water problems in the downstream Oued Mellègue sub-basin, the proposed management plans have put in place a new water policy based on Principles of integrated resource management, as well as deep institutional, legal and organizational reforms in line with the seriousness of the problems to be addressed. Thus, in addition to the considerable investments already made, priority has now been given to the water resources sector as part of the economic recovery plan, which covers: - Update the hydraulic register of the region of Tébessa.

- The maintenance of infrastructures and the systematic mobilization of all available resources.

- Use of non-conventional resources, including wastewater recycling and desalination of seawater. 
- Implementation of planning, management and communication tools.

Protection of existing resources, rehabilitation of drinking water, sewerage and sewage treatment systems

-Meeting the needs of A.E.P and fighting waterborne diseases by providing citizens with water of sufficient quality and quantity.

- Schedule new surveys to reveal other aquifers and carry out all major groundwater balance studies in the north and south, and quantify all groundwater in order to get an idea of the Quantity of water that we can mobilize in the future.

- Fight against pollution, waste, leakage, unauthorized extraction and illegal tapping.

- Exploitation of water resources for tourism development: Water consumption linked to tourism is one of the major issues facing host communities or institutional managers (creation of tourist campsites ,Ain Gastel, commune of Ain Zerga).

To sensitize the citizens of the area with all possible means (pamphlets, posters, study days, seminars, radio, internet and other), and draw their attentions on the value of water in the climatic context Of the country and of the wilaya and their water limits, because any strategy of water management requires their understanding and mobilization.

\section{References}

Al Kuisi, M. (1998). Effects of irrigation water with special regards to biocides on soils and groundwater in the Jordan Valley area, Jordan. Münster. Forsch Geol Paläont, 84, 1-173.

Blés, J. L., \& Fleury, J. J. (1970). Carte géologique de l’Algérie au 1/50000 : feuille n¹78, Morsott, avec notice explicative détaillée. Service de cartes Géologique et Sonatrach, Division d'hydrocarbure. Direction explorations, Alger, Algerie.

Davis, S. N., \& Wiest, D. (1967). Hydrogeology - John Willley and Sons, 463p. New York.

Djabri, L. (1996). Mechanism of Seybouse water pollution and vulnerability, geological, industrial, agricultural and urban origins. Doctorate Thesis, University of Annaba, 176p.

Drever, J. F. (1997). The geochemistry of natural waters. 3rd ed. New York - Prentice-Hall INC, 379p.

Fehdi, Ch. (2008). Apport hydrogéochimique et isotopique dans la caractérisation des mécanismes d'acquisition de la salinité des eaux souterraines du complexe aquifère.

Fidelibus, M. D., \& Tulipano, L. (1996). Regional flow of Intrusing sea water in the carbonate aquifers of Apulia (Southern Italy). Proceedings $14^{\text {th }}$ Salt Water Intrusion Meeting. Rapporter och meddelanden $n r, 87$, pp. 230-241.

Fontes, J. Ch., Yousfi, M., \& Allison, G. B. (1986). Estimation of long term, diffuse groundwater discharge in the northern Sahara using stable isotope profiles in soil water. J. Hydrol, 86, 315-327.

Fritz, J., \& Fontes, J. (1980). Handbook of environmental isotope geochemistry. Elsevier, Amsterdam, (A'), p21.

Gimenez E. and Morell L. (1997). Hydrogeochemical analysis of salinization processes in the coastal aquifer of Oropesa (Castellon, Spain). Environmental Geology, 29, 118-131. Springer-Verlag, Berlin; Heidlerg.

Morsott-El, Aouinet (N.E. Algérien). Thèse de Doctorat- es-sciences, Université de Annaba, Algérie.

Rouabhia, A., Fehdi, Ch., Baali, F,. Djabri, L., \& Rouabhi, R. (2008). Impact of human activities on quality and Geochemistry of groundwater in the Merdja area, Tebessa, Algeria. Environmental Geology, Springer-Verlag, Berlin; Heidlerg.

Salameh, E. (2001). Sources of water salinities in the Jordan Valley Area, Jordan. Acta hydrochim hydrobiol, 6-7, 329-362.

Vila, J. M. (1980). La chaîne alpine de l’Algérie orientale et des confins Algéro-Tunisiens. Thèse de Doctorates-sciences, Université Pierre et Marie curie, Paris VI.

\section{Copyrights}

Copyright for this article is retained by the author(s), with first publication rights granted to the journal.

This is an open-access article distributed under the terms and conditions of the Creative Commons Attribution license (http://creativecommons.org/licenses/by/4.0/). 